\title{
Meanings attributed by nursing staff about permanent education in cardiovascular institution*
}

\author{
Significados atribuídos pela equipe de enfermagem sobre educação permanente em uma \\ instituição cardiovascular
}

Cintia Koerich ${ }^{1}$,Alacoque Lorenzini Erdmann ${ }^{1}$

\begin{abstract}
Objective: to understand the meanings attributed by the nursing staff to permanent educational practices in a reference cardiovascular hospital. Methods: this is a qualitative study, which used the Grounded Theory in Data for collecting and analyzing data. The sample consisted of 22 nursing professionals. Results: the study presents two categories that highlight the need for further clarification of the nursing staff about the concept of permanent education in health, as well as reinforce the permanent education of nurses as a management practice which needs to be incorporated into other assignments in daily work. Conclusion: it is admitted the need to work the concepts of permanent education in health even in professional qualification, as well as place greater emphasis on managerial training of nurses, so they acquire the power to take their assignment as a nursing care manager and the nursing staff education contribute to the necessary changes in the health services. Descriptors: Nursing; Health Management; Education, Continuing; Cardiology Service, Hospital.
\end{abstract}

Objetivo: compreender os significados atribuídos pela equipe de enfermagem às práticas de educação permanente em um hospital referência cardiovascular. Métodos: estudo qualitativo, o qual utilizou a Teoria Fundamentada nos Dados para coleta e análise dos dados. Participaram do estudo 22 profissionais de enfermagem. Resultados: apresenta duas categorias que evidenciam a necessidade de maior esclarecimento da equipe de enfermagem sobre o conceito da educação permanente em saúde, assim como reforçam a educação permanente como prática gerencial do enfermeiro a qual precisa ser incorporada às demais atribuições no cotidiano de trabalho. Conclusão: admite-se a necessidade de trabalhar os conceitos da educação permanente em saúde ainda na formação profissional, assim como dar maior ênfase a formação gerencial do enfermeiro de modo que este adquira competência para assumir sua atribuição como gestor do cuidado de enfermagem e da educação da equipe de enfermagem contribuindo para as mudanças necessárias nos serviços de saúde. Descritores: Enfermagem; Gestão em Saúde; Educação Continuada; Serviço Hospitalar de Cardiologia.

\footnotetext{
*Extracted from the dissertation entitled "Vislumbrando a gestão das práticas de educação permanente na emergência do cuidado qualificado em cardiologia”, Universidade Federal de Santa Catarina, 2014.

${ }^{1}$ Universidade Federal de Santa Catarina. Florianópolis, SC, Brazil.

Corresponding author: Cintia Koerich

Rua Acelon Pacheco da Costa, 231, Bloco B ap 302, Itacorubi, CEP: 88034040. Florianópolis, SC, Brazil. E-mail: cintia.koerich@gmail.com
} 


\section{Introduction}

Considering the increasing incidence of people suffering from non-communicable chronic diseases, in particular circulatory system diseases, and the consequent increase in the number of hospitalizations and specialized care needs ${ }^{(1)}$, as well as the current innovation speed of knowledge and technology, it is expected that the health care staff be prepared to offer adequate support to this demand with the objective of improving the quality of provided care. In this context, nurses as a care manager, must seek the permanent qualification in their work and stimulate the health staff.

The nursing care of the cardiac patient requires scientific knowledge and expertise combined with technical skill, and as a tool to facilitate these actions, the sensitivity is included, humanization and respect by the relationships and interactions established between the patient, family and professional ${ }^{(2)}$. In this sense, it is expected that the nursing staff, to understand the complexity of the problem of cardiovascular diseases and its complex relationships and interrelationships in the health-disease process, especially in a complex care environment, such as the hospital, be able to discuss strategies to favor a quality care to the individual affected by cardiovascular disease.

It can be said that human understanding is essential for education since it must also understand the objective and subjective conditions of human nature, that is, understanding requires awareness of human complexity. Thus, to understand certain phenomenon it is necessary to emerge and submerge in the context of the uniqueness of every human being and the complex relationships, interactions and interrelationships that it establishes itself, with the environment, and with others ${ }^{(3)}$.

In this perspective, the National Policy on Permanent Health Education of the Ministry of Health was established by Decree 198 of 2004, reviewed later in 2007, which were considered the devices presented in the Pact for Health, Pact for Life and Management ${ }^{(4)}$. This policy seeks to reinforce the need for change in professional training, guided by biomedical positivism model and makes critical pedagogical approaches focused on upright educational processes, emphasizing the development of technologies that consider the production of participatory subjectivities ${ }^{(5)}$.

The permanent education is anchored in meaningful learning and in the possibility of transforming professional practices. It is performed in the daily work, from the problems faced in this environment, and considers the knowledge and experience that professionals already have. It proposes that the process of health professionals learning starts from the questioning of the work process and that the formation considers the health needs of individuals and populations, aiming at the transformation of professional practices and work organization ${ }^{(4)}$.

In this sense it can be thought of continuing education in health as a management tool of nursing care to cardiac patients, and it is possible to improve the quality of care using permanent education, i.e., from the implementation of actions that seek complexity understanding, involved in human interrelations, the workplaces and the very process of health and disease. It is considered that through the experiences analysis of continuing education becomes possible to realize/understand the possibilities and difficulties in the work process, as well as the strategies, skills and necessary attitudes ${ }^{(6)}$.

Given the above, the question is: Which meanings the professional nurses actives in a reference cardiovascular hospital, attribute to permanent educational practices? This study aimed to understand the meanings attributed by the nursing staff to permanent educational practices in a reference cardiovascular hospital.

\section{Methods}

This is a qualitative, exploratory, and descriptive study, which used complex thinking as a theoretical ${ }^{(7)}$ 
and Grounded Theory in Data as a methodological reference ${ }^{(8)}$.

The complexity can gather, to contextualize, to globalize, but at the same time, can recognize the singular, individual, concrete. Different from the fragmented and independent thinking, the complex thinking sets in another way of approaching reality ${ }^{(7)}$. The complex thinking emphasized the "Human" and defined it as complex. Therefore, it is important to know/understand/realize the complex structure of human nature, and also contemplates the environment/habitat in which the human being is inserted, to value human life in its uniqueness and plurality of being(7).

Two sociologists, Barney Glaser and Anselm Strauss in the 60s, originally developed the Grounded Theory in Data. Such method provides that the theory is derived from the data, i.e., emerges from systematically gathered and analyzed data by the researcher through a search process ${ }^{(8)}$. The authors propose the standard model for conducting the research and development of the theory, which is an organizational scheme, which helps to gather and sort the data systematically, so the structure and process would be integrated, and the phenomenon visualized. The basic components of the paradigm are the unusual conditions, contextual conditions, intervening conditions, strategic interactions, and consequences. The phenomenon is the term that answers the question: What is happening here? This means answers to problems and situations in which people $\operatorname{are}^{(8)}$.

Data collection was developed in a public health hospital of cardiovascular reference for the state of Santa Catarina, between June and October 2014, through individual interviews and digital voice recording. Nurses and technicians in nursing participated in the study, totaling 22 participants, who were divided into three sample groups as required by method ${ }^{(8)}$. The Grounded Theory in Data enables searching local, people or facts allowing the discovery of the investigated phenomena, without being provided at baseline. The theoretical sample progresses, becomes more objective and focused as the search progresses, until emerging a new or important data (theoretical saturation) and the categories were well developed in its properties and dimensions ${ }^{(8)}$.

The data collection process, for the construction of Grounded Theory in Data, initiated by a central and broad question. Later, other derived questions were addressed to participants to explore the meanings through an in-depth interview. According to the Grounded Theory in Data, the guiding question of the interview must be open and wide, to allow flexibility and freedom to explore the in-depth phenomenon, i.e., exploring the full of the expression meaning reported by the participant ${ }^{(8)}$.

The interviews were coded line by line and analyzed in a way that other questions and hypotheses were raised to guide the next interviews/ sample groups. To confirm the hypotheses raised the need to interview nurses involved in direct assistance to the cardiac patient, as well as managers involved with educational practices in the institution, as the following three sample groups:

First group: 10 nurse managers of nursing care. Question: How do you mean the permanent education practices as nurse manager of nursing care active in a reference cardiovascular institution?

Hypothesis: the professional improvement practices offered by the institution, such as courses and lectures, no longer meet the needs of professionals, and therefore, do not have the interest in participation.

Second group: 7 assistance professionals, 4 nurses and 3 nursing technicians.

Question: How do you experiences the permanent education practices in your daily work?

Hypothesis: The opportunities, propagation and institutional incentives for permanent educational practices are incipient, hampering the adhesion of professionals identifying other proposals that meet their needs and learning conditions at work.

Third group: 5 nurse managers involved with educational practices in the institution. 
Question: How do you mean the permanent education practices offered/experienced in this institution?

The group participants were identified, respectively, by the letters "NI" (Nurse Interview), "AI" (Assistance Interview) and "MI" (Managers Interview), followed by the corresponding number to the interview order within each group, to preserve the identity of participants.

Data analysis was proceeding by three respective steps; wherein the compliance of one step does not necessarily means preventing the return to the first since the movement is circular. These three stages are denominated: open coding, axial coding, and selective coding. The encoding process aims to reduce the data and corresponds to the analytical process in which data are divided, named, conceptualized, and integrated to form the theory ${ }^{(8)}$. Data were organized in NVIVO software, to facilitate the analysis of the data volume.

From the meanings evidenced in the categories and the primary category and their interrelationships, an explanatory theoretical model was elaborated, emerging from the data, the study phenomenon: "Glimpsing the management of permanent educational practices, in the emergence of nursing care skilled in cardiology". A nurse with knowledge in the subject validated the theoretical model. The five categories and its respective subcategories, which are part of the theory constructed in this study, are described in full in the master's thesis ${ }^{(9)}$.

On this manuscript, a re-reading of the data was performed, with emphasis on the meanings given by the nursing staff about permanent education on the relevance of this approach, and the results were presented in two categories.

The study complied with the formal requirements contained in the national and international regulatory standards for research, involving human beings.

\section{Results}

The results are presented in two categories, which are: knowing the concepts of the nursing staff about permanent education and realizing permanent education as a management practice of nurses.

\section{Knowing the concepts of the nursing staff about permanent education}

Most of the study participants refer to continuing education, in-service education and permanent education as synonymous. They cite training, congresses, courses, classes, and lectures, in an isolated and timely manner as permanent educational practices. As health education, is also related to permanent education for professionals. What would be the permanent education? These training, participation in events and all the great knowledge in the area (NI2). I think we could have the question to be offering more courses in our routines, and having refresher courses, both on the part of drug dilutions, stop maneuver [cardiorespiratory], these things, because it comes very new employee and sometimes you don't have this training. I think we could have more refresher courses (AI7). Permanent education, the name says that it is permanent, and then it is constant that we need to be guiding and educating patients every day (NI3).

This conception of professionals about permanent education can be related to how the training industry operates in the institution. This performance is characterized by lectures and prebooked courses, with little relation to the practical needs of professionals, which hinders the adhesion of workers. The offered educational practices are not usually evaluated. Nuclear medicine is scheduling another basics course of nuclear medicine and ministers every year, and then every year we offer this course, they [the training sector] organize a course along with you and they are responsible for the physical environment, and for inviting speakers (NI7). There is a training sector within the hospital, organized lectures. But what happens? Within a team everyone needs, but at the moment to dismiss these people not 
everyone can go or not everyone is interested, because sometimes is a lecture they do not like, the subject is not attractive (NI3). Is not only teaching a course, is to give the course and then evaluate, is to come back again to teach the course, to feel the necessary always to give this course (NI5).

It is possible to perceive that most participants unknown the logic of permanent health education. Although some nurses, especially the management group, recognize that the training sector of the institution does not usually follow the logic of permanent education, but performs activities that have a closer relationship with the concept of continuing education, it is necessary to deepen concepts. How can I realize the permanent educational practices here at this institution? Can I say that I do not realize? Can I say that there is no permanent education? (MI4). People who work in the service nowadays [training sector] they are focused on other things, to provide some courses that I do not see as permanent education, for me permanent education has a concept, to provide certain courses does not cease to be a education, an information, a training course, but maybe is not directed to your problem, what really you need (MI2). Talking about permanent education, I do not know or say if permanent education happens here, what we more have continuing education, which is a specific issue worked on lectures and courses. But the question of permanent education to work the critical nodes of each workplace because it arises from the labor process, we still cannot move (MI3).

However, some professionals demonstrate an understanding that the logic of permanent education goes beyond courses and point and special lectures, referring to permanent education as a continuous exchange of knowledge in the workplace. They relate the permanent education to the quality of the nursing care and safe nursing care, as well as reveal that nurses need to have initiative and worry to modify/improve nursing care. We perform it at the workplace. We arrive and see the points that could be improved, what we could make agile to the patient at that time, what went wrong with the staff. This we have always done (NI10). The permanent education is the learning of what you do, what you are exercising or what you can exercise. Then, permanent education is a continuity of knowledge (AI2). I think that permanent education and care are closely linked, but it is a matter of the person's initiative and to believe that if you generate knowledge, if you have knowledge, if you take ownership of knowledge, you will execute a care very more security (NI8).

Most nurses believe it is not possible to change the attitude of professionals who do not have adherence to permanent educational practices. However, some professionals, especially mid-level, refer to miss opening and motivation for participation and involvement in the educational practices. This is already about the person [initiative and interest] can help, may improve, but this is something about the person. A large is already part of creation, education, you cab polish a bit, but it has to come with the person also (NI9). This permanent education gets lost a little because when you do not receive that stimulus for your work with permanent education, you already begin to prune and less interested in that $(\mathrm{AI} 2)$.

Professionals report that the Distance Educational Courses/online can also be used as part of permanent education on the ease/convenience of access to information and the lack of time of the nursing staff to attend classroom courses. But now at this time of Internet, they seek knowledge direct in the system (NI6). In the distance learning, you open your computer, you do the courses (NI7). They have low adherence to classroom course, but when through the Internet, there are many courses, and one passes to the other, and they do because they can do when they have time, in the vague time during the service (NI4).

It is necessary a change of the nursing professional attitude favor the interaction between staff members to discuss the practice and seek other logic for education in service, aimed at overcoming the traditional way in which educational practices are experienced in health institutions. Considering that the traditional logic of education of health workers should not be discarded, but rather be complementary to a new process that is needed.

\section{Realizing the permanent education as a managerial practice of nurses}

Although some nurses recognize their responsibility with the practice of managing the permanent education of the nursing staff in the 
institution, others attribute this function only to the training sector. Other participants still await partnerships, not feeling entirely responsible for the process. The responsibility is both the staff working with the permanent education [training sector] as mine, I feel responsible as a nurse, and I have this responsibility to pass on to my group. The responsibility is theirs [training sector] but it's my responsibility as a nurse (NI10). What I understand: first, that the institution is needed of permanent education, and second that we expect that a sector train us, so we transfer the blame for a sector [training] (MI4). It is everyone's responsibility, but the effectiveness I think it comes cascading, it can not be from the bottom to the top, it is not the group that have to self-help, because there does not need the macro (MI2).

Some participants reported that the lack of commitment of some nurses to the management of continuing education would be the responsibility of the institution as it does not encourage and available time to involve these professionals in the educational process. Also reveal the difficulty of finding nurses with management profile and the limited time available for these professionals to get involved in the educational practices, due to the time given to the staff dimensioning, among other duties. The permanent education is bodily, as they [the nurses] did not have it; they have no commitment to anything that is done here. The nurses are not also involved in the permanent education process. Because it was not something given to them (MI2). There are the leadership and has trouble with managers because they have no preparation. To get nurses to manage sectors is very difficult today, I had no nurses prepared to manage many services here, and then I was working some of them (MI3). It takes a long time, there are many servers and I believe that most managers within the Health Department waste time with scale, the scale takes a long time to be made with few servers, and also all attestations arriving during the month that you have to organize, call someone, exchange shifts (NI2).

Nurses, to manage educational practices that meet the logic of permanent education, seek alternatives to consolidate such practices using onsite training, simulation and participation in formal groups for discussion. Such actions, sometimes, are directed to the technical dimension of work; however, ethical, political and interpersonal relationship issues are cited as a concern among professionals. It was made here in the coronary, with respirator training and the physiotherapist explained the procedures and how to use the respirator. We had training about cardiorespiratory arrest, and also practical in coronary and about the use of infusion pump (AI4). So we have to go working on-site. The proposals of our permanent education sector [training] are lectures, so I think we have to evaluate (MI2). There are discussions, debate about something, I do not only receive [information], a study group is when everyone goes and participates, is not only a lecture where a professional gives information (AI3). Interpersonal issues are a major critical node in the institution; it is necessary to work these issues (MI3).

Supervision of nursing staff appears as nursing management action that favors the permanent educational practices because it allows recognizing the needs of knowledge and guidance on staff. So the nurses reported that seek to contribute to the continuing education practices, guiding and opening opportunities for discussion on the working day, observing and listening to the needs of professionals as well as requesting the partnership training sector, to give a feedback to the identified needs. The nurse is responsible for assessing the technical conditions of each worker that has the team, even if just come to meet schedule, they have a team, they are part of this team, and they are the responsible (MI3). I can there [in the workplace] to make the permanent education: is better to do like this, is better to massage like this, and is better to punch on that way. So I do that kind of thing, every day, with all the people here. I always thought the point answer is better than collective courses. I think that solve specific questions and direct and continuing observation is a permanent education better to make a collective education with courses, I believe much more in the permanent presence next to the person (NI8). There was my observation, of all nurses, even from other sectors, other professionals and especially the request of nursing technicians, all they request training, not only the new ones, but the old as well, because things change and we need to be always updated. So it was general, all observed the need, and I took to the training sector (NI2). What I continually experience is permanent education, with nursing technicians and even with a colleague nurse (AI4).

Nurses sometimes show unfamiliar to the permanent education process of the nursing staff, 
seemingly unaware their attributions as supervisor and educator. The incipient support of the institution, the amount of attributions and the difficulty of finding nurses with management profile, are factors that seem to influence negatively, the involvement of the nurse as manager in the permanent educational process. However, there is the initiative of nurses seeking alternatives to manage permanent educational practices, effective at the institution, seeking their workplace as space for interaction and discussion among professionals.

\section{Discussion}

Most nurses and nursing technicians showed to ignore the conceptual basis of permanent education, sometimes, confused with the concept of continuing education and in-service education, which can hinder theprocess of change in thehealthscenario, considering that tend to reproduce the education model used by the institution. The continuing education and inservice education are important for the development of workers for its complementary nature ${ }^{(10)}$, however, for the transformation of healthcare practices, the discussion of permanent health education is essential, as a public policy to be implemented at all levels of care from the Unified Health System.

In this sense, the experience in a teaching hospital in southeastern Brazil about the implementation of permanent education, shows that the medium and long term workers can broaden their expectations for a critical view of the work as well as in relation to professional/user interaction, and a theory/practice articulation, at an understanding of education at work, guided by permanent education ${ }^{(11)}$.

Professionals commented that the educational practices offered by the institution training sector has little relation to its labor needs, as well as an evaluation of the result of such practices for nursing care is not taken. It can be concluded that such practices will meet the logic of the continuing education in health, considering that work on an uni- professional way, as an autonomous practice, sporadic and uses methodologies based on the pedagogy of transmission, seeking to reach the appropriation of knowledge in a passive way ${ }^{(10)}$ and without context with the professional reality. Thus, for the practice of permanent health education, it is essential the triad planning, methodology and evaluation ${ }^{(12)}$.

Some participants seem to understand the logic of permanent education and cite the workplace as an important exchange space, whether through formal meetings used for discussion groups as well as informal in daily work. The opportunity of health worker to be in group to discuss everyday problems allows them to be perceived as part of the work process and thus, be positioned in a more active and participatory way, glimpsing a more shared management in the hospitals and transforming the vertical power, present in these spaces, in an horizontal power ${ }^{(13)}$.

In this context, it can be affirmed that knowledge is not only to diversify a culture but also to change the attitude of the human being to propose and solve problems. However, knowledge of information itself does not make sense to human; this information must be placed in a context that is not abstract ${ }^{(3)}$.

Professionals commented that use the Distance Education as a resource on the convenience/ease of access to information and difficulty in participating in classroom courses. The Distance Education can be considered a permanent educational strategy, that when implemented in the workplace, can facilitate the educational process at work because it allows, even professional not being in shared space and time, knowledge exchange happens, considering the professional nursing profile that has more than one job and difficulty to be absent during working hours to participate in educational activities ${ }^{(14)}$.

Regarding the involvement in the management practice of permanent education, some nurses demonstrated little understanding of their attributions, as well as unprepared to exercise that function. It is possible to observe that nursing education devalues managerial aspects, such as leadership, for example, 
that is often only perceived by nurses when inserted in professional practice and faced with situations that require this professional competence ${ }^{(15)}$.

Thus, it is perceived the need to train and insert the appropriate professionals into the labor market, to perform management functions in health. Being necessary to intensify professional and permanent education of nurses to the management of nursing care practice, seeking to integrate knowledge, skills and attitudes to ethical care, with safe and quality to human and community ${ }^{(16)}$.

The participation of nurses in continuing education centers, at a university hospital in southeastern Brazil, allowed the development of guidelines for structuring the permanent education service in the institution and allowed the nurse, as leader of the nursing team, to facilitate educational activities, raising the understanding about the importance of involvement and responsibility for their own professional education, given the apparent removal of its leading position in the nursing staff, and strategic professional so that the changes will be consolidated in health services ${ }^{(17)}$.

However, in this study, some professional's emphasizes the limited available time to engage with the permanent educational practices because some attributions they perform in daily work. It is worth mentioning that in the hospital sector the permanent education development process in most cases is not as important as other problems faced and considered priority as lack of human resources, professional demotivation and work overload ${ }^{(12)}$.

Thus, despite the incipient support of the institution to the educational practices, nurses seek strategies to manage permanent educational practices, although often focusing technicalities permeates this dimension to mention the concern for ethical, political and interpersonal relationships issues. Corroborating with a study where nurses revealed a broader view of permanent education, considering the political and ethics issue, even though they cover the technical dimension of work, and reported that given the lack of institutional planning for permanent educational practices uses other spaces and strategies taking advantage of moments during the working day to carry out the educational process ${ }^{(12)}$. Thus, even not providing a structured and formal permanent educational service, initiatives happen with a different proposal, in an organized manner to promote participation and dialogue $\mathrm{e}^{(12)}$.

It is noticed that the technical expertise is considered an important concern in the nursing staff and the educational service has a strong grip on the technical dimension of work in the hospitals since most of the professionals requests involves this dimension ${ }^{(18)}$ and considering that the very training tends to valorize $\mathrm{it}^{(15)}$. However, it is noteworthy that the nursing care management constitutes a complement to the nursing work process, and care should be managed within institutions with rationality and sensitivity exceeding technical principles ${ }^{(19)}$.

Nurses also evidence the supervision as a management action, able to permanent educational practices, as it enables to recognize demands and make changes in their workplace. Supervision in nursing is considered an important management tool for monitoring, evaluation and education of the nursing staff. Thus, when held in pedagogical and cooperation character, can promote social and political interaction of workers ${ }^{(20)}$.

\section{Final Considerations}

The meanings attributed by nursing professionals to permanent educational practices are related to the quality of the nursing care, to safe nursing practice, to the need for openness and spaces for discussions on everyday labor, to the use of technologies and innovative practices of professional education, the importance of institutional support, the interaction between the health team and the work of nurses as nursing care manager using resources such as the supervision of the nursing staff, time management and use of formal spaces for discussions 
about ethics and politics in the profession.

It highlights the need to work the concepts of permanent education in health even in professional training, as well as giving greater emphasis to the management nursing education, to overcome the technical dimension, thus the nurse acquires competence to take their attribution as care managers and of the nursing staff education, contributing to the necessary changes in the health services.

The study presents as limitation the fact that it was conducted in a health institution specialized in cardiology, which influence professionals to emphasize the disciplinary fragmentation related to the experience of institutional routine.

It points out the importance of studies, which designate possibilities of working the perspective of permanent education in high complexity health.

\section{Collaborations}

Koerich C participated in the project design, collection and analysis of data and writing and critical analysis of the article. Erdmann AL contributes to writing and critical analysis, and final approval of the version to be published.

\section{References}

1. Ministério da Saúde (BR). DATASUS. Sistema de informações hospitalares. [Internet]. 2013 [citado 2015 jun 15]. Disponível em: http://tabnet. datasus.gov.br

2. Fernandes MJC, Silva AL. Significados do cuidado de enfermagem à pessoa idosa em cuidados intensivos. In: Silva AL, Gonçalves LHT. Cuidado à pessoa idosa - Estudos no contexto luso-brasileiro. Porto Alegre: Sulina; 2010. p. 49-109.

3. Morin E. Os sete saberes necessários à educação do futuro. São Paulo: Cortez; 2011.

4. Ministério da Saúde (BR). Secretaria de Gestão do Trabalho e da Educação na Saúde. Departamento de Gestão da Educação em Saúde. Política Nacional de Educação Permanente em Saúde. Brasília: Ministério da Saúde; 2009.
5. Nespoli G, Ribeiro VMB. Discourses that form knowledge: an analysis of the theoretical and methodological conceptions that guide the educational material for the training of facilitators of Continuing Education in Health. Interface Comun Saúde Educ. 2011; 15(39):985-96.

6. Stroschein KA, Zocche DAA. Educação permanente nos serviços de saúde: um estudo sobre as experiências realizadas no Brasil. Trab Educ Saúde. 2011; 9(3):505-19.

7. Morin E. Introdução ao pensamento complexo. Porto Alegre: Sulina; 2011.

8. Strauss A, Corbin J. Pesquisa qualitativa: técnicas e procedimentos para o desenvolvimento de teoria fundamentada. Porto Alegre: Artmed; 2008.

9. Koerich C. Vislumbrando a gestão das práticas de educação permanente na enfermagem em uma instituição cardiovascular à luz da complexidade [dissertação]. Florianópolis: Programa de PósGraduação em Enfermagem, Universidade Federal de Santa Catarina; 2014.

10. Peixoto LS, Gonçalves LC, Costa TD, Melo CMT, Cavalcanti ACD, Cortez EA. Permanent, continuous and of use Education: revealing its concepts. Enferm Glob. 2013; 12(1):307-22.

11. Montanha D, Peduzzi M. Permanent education in nursing: survey to identify the necessities and the expected results based on the workers conception. Rev Esc Enferm USP. 2010; 44(3):597-604.

12. Lino MM, Backes VMS, Ferraz F, Prado ML, Fernandes GFM, Silva LAA, et al. Permanent education in the public health services in Florianópolis, Santa Catarina. Trab Educ Saúde. 2009; 7(1):115-36.

13. Pereira FM, Barbosa VBA, Vernasque JRS. Continuing education experience for auxiliary nurses as a management strategy. Rev Min Enferm. 2014; 18(1):228-35.

14. Silva NA, Santos AMG, Cortez EA, Cordeiro BC. Limits and possibilities of distance learning in continuing education in health: integrative review. Ciênc Saúde Coletiva. 2015; 20(4):1099107.

15. Amestoy SC, Cestari ME, Thofehrn MB, Milbrath VM, Trindade LM, Backes VMS. Education process of nurse leaders. Rev Bras Enferm. 2010; 63(6):940-5. 
16. Senna MH, Drago LC, Kirchner AR, Santos JLG, Erdmann AL, Andrade SR. Meanings of care managementbuiltthroughoutnurses' professional education. Rev Rene. 2014; 15(2):196-205.

17. Jesus MCP, Fiqueiredo MAG, Santos SMR, Amaral AMM, Rocha LO, Thiollent MJM. Permanent education in nursing in a university hospital. Rev Esc Enferm USP. 2011; 45(5):1229-36.

18. Salum NC, Prado ML. Continuing education in the development of competences in nurses. Texto Contexto Enferm. 2014; 23(2):301-8.
19. Montezelli JH, Peres AM, Bernardino E. Institutional demands and care demands in the management of nurses in an emergency unit. Rev Bras Enferm. 2011; 64(2):348-54.

20. Santiago ARJV, Cunha JXP. Supervision in nursing: promoting quality of assistance. Rev Saúde Pesq. 2011; 4(3):443-8. 